\title{
DESCRIPTIONS OF SOME NEW TROPICAL PACHYGASTRINA.
}

\author{
By Charles W. Johnson, \\ Boston Society of Natural History.
}

In describing a species of Psephiocerafrom Jamaica, my attention was called to two apparently new species, representing one Psephiocera and one Chalcidomorphina from British Guiana. The above genera by Dr. Enderlein cover these forms, while a paper by Dr. Kertész enables us positively to determine Cynipimorpha. With the limited material at hand, it is with some misgivings that I offer this paper, but the difficulty of obtaining smaller species from that region is so great that years slip by and they remain undescribed. For instance, the specimens at hand have been in my possession over eighteen years. It is to be hoped that the following bibliography and table of species will aid future workers.

\section{Cynipimorpha bilimeki Brauer. Fig. 1.}

C. bilimeki Brauer, Denkschr. der K. Akad., Wien, XLIV, 75, 1882;

Kertész, Ann. Mus. Nat.Hung., VI, 343, Tab.6, Figs. 1, 2, 1908.

In the latter paper Dr. K. Kertész has carefully redescribed Brauer's type and figured the antenna, thus enabling one to readily identify this species which otherwise would have continued to cause confusion among the closely related genera and species. I herewith reproduce the figure given by Kertész. The genus has been emended to Cynipomorpha by Enderlein, but the original spelling will have to stand.

\section{Psephiocera Enderlein.}

Zoölogischer Anzeiger, 1914, Band 43, p. 300. Type P. flavipes Enderlein.

Table of Species.

1. Tomentum forming lines on the disc of the thorax........

Tomentum covering the entire thorax .............

2. Scutellum and part of the pleura with light tomentum (Mexico) minuta Will.

Scutellum with black tomentum, pleura shining black without tomentum (S. Brazil).............. flavipes Enderl. 
3. Thorax with three lines of light tomentum which is also present on the sides, and on the middle of the pleura (Jamaica)

metzi Johns.

Thorax with a dorsal line of light tomentum, expanding into a large patch in front of the scutellum, also present on sides and on part of pleura (Brit. Guiana).... dorsata sp. nov.
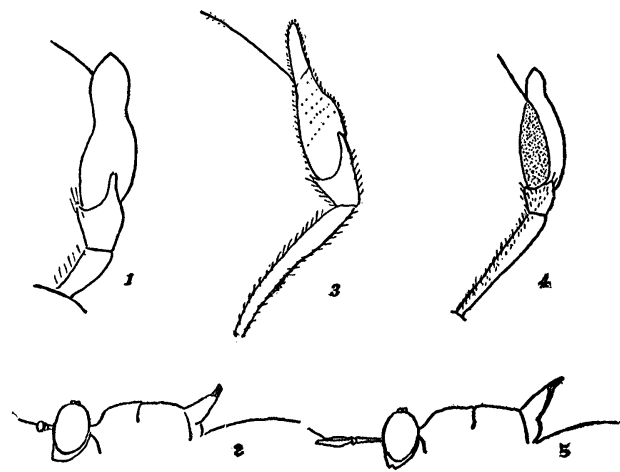

Fig. 1. Antenna of Cynipimorpha bilimeki $\sigma^{\curlyvee}$, after Kertész; Fig. 2, scutellum of Psephiocera minuta; Fig. 3, antenna of Chalcidomorphina aurata $\$$, after Enderlein; Fig. 4, antenna of Chalcidomorphina crewi , Fig. 5; Scutellum of same.

Psephiocera minuta (Williston). Fig. 2.

Cynipimorpha minuta Williston, Biol. Cent. Amer., Vol. I, p. 252, Tab. 4, Figs. 19, 19a, 1901; Kertész, Ann. Mus. Nat. Hung., Vol. 4, p. 343, 1908.

Psephiocera minuta Enderlein, Zoöl. Anz. Band 43, p. 302, 1914. Eucynipimorpha minuta Malloch, Ann. Ent. Soc. Amer., Vol. 8, p. 312, 1915.

As pointed out by Dr. K. Kertész this species cannot be placed in the same genus with Cynipimorpha bilimeki Brauer on account of the great difference in the antennæ. It was later placed by Dr. Enderlein in the above genus. A specimen in my collection from Mexico agrees with Williston's description except that the femora are yellow with a slight brownish tinge below, and not "except the tips, nearly black." This is evidently a variable character and the specimen probably represents the extreme range of variation in this respect. The third joint of the antennæ under a hand lens (12 diameters) is "finely roughened" but under the binocular with 
an enlargement of from 25 to 60 diameters the annuli show distinctly and the roughening is due to rows of minute granules on the annuli; the third joint is yellow with a dark brown spot at the base. In this respect the genus seems to be closely related to Neopachygaster, the glossy brown spot on the antennal joint, which Malloch refers to as "possibly of a sensory nature," is here largely developed. The only other character that seems to separate the two genera is the form of the scutellum. The side view given of $C$. minuta (fig. 19a) shows two small dorsal protuberances at the suture that are not mentioned in the description, nor are they shown in the dorsal view (fig. 19).

\section{Psephiocera metzi Johnson.}

Diptera of Jamaica, Amer. Mus. Nat. Hist., Vol. 41, p. 427, 1919.

The apex of the scutellum is slightly shorter and less attenuated in this and the following species, than in P. minuta Will.

Psephiocera dorsata sp. nov.

$\varsubsetneqq$ Front black, orbital margins whitish, face white, antennæ yellow, the third joint with five narrow annuli, with a small brown basal spot, arista yellow. Thorax black when viewed from above, the yellowish tomentum forming a dorsal line extending just beyond the suture where it expands into a broad patch in front of the scutellum; there is also an obsolete transverse band in front of the suture; from the humeri large patches of whitish tomentum extend to the base of the wings and across the pleura; base of the scutellum with yellowish tomentum. Abdomen black, looking from behind the fourth segment has three lines of white tomentum, with only the dorsal line showing on the fifth segment, third segment with only a lateral patch when viewed from the side. Legs yellow, femora except at the tips dark brown, front tibiæ also brown, halteres white. Wings hyaline, costa and first longitudinal vein dark brown, stigma yellow, length, $3 \mathrm{~mm}$.

One specimen, Bartica, British Guiana, May 28, 1901 (R. J. Crew). Type in the author's collection.

Chalcidomorphina Enderlein.

Zoologischer Anzeiger, 1914, Band 43, p. 298. Type C. aurata Enderlein. 
Chalcidomorphina aurata Enderlein. Fig. 3.

Zoologischer Anzeiger, 1914, Band 43, p. 299, figs. 4, 5. Columbia.

The principal character that separates this from the following species is the form of the antennæ. The scutellum of the genotype was missing, but it is probably similar to the following species which is here figured.

Chalcidomorphina crewi sp. nov. Figs. 4, 5 .

o Face black, whitish pollinose, front black shining, with white orbital spots midway between the vertex and antennæ, from these very narrow orbital lines extend to the face, ocelligerous tubercle prominent, ocelli yellow, antennæ situated about the middle of the head in profile, blackish above and yellow below, first joint slender, about as long as the second and third combined, third joint broadened and somewhat flattened above and minutely flecked with white. Thorax black, with a dorsal line, a narrow transverse band at the suture, and a broad band near the base of the scutellum of yellow tomentum, on the humeri and pleura whitish, scutellum black, the tip longer and more attenuated than in the species of the genus Psephiocera, abdomen black, with agrayish pollinose arcuate band at the posterior margin of the third and anterior margin of the fourth segment, and a V-shaped marking at the end partly on the fourth and partly on the fifth segment. Legs yellow, the anterior femora brownish, halteres white. Wings hyaline with a slight brownish tinge, more noticeable toward the tip, veins brown, stigma yellow, middle portion of the costa and tip of the first vein dark brown, third vein branched. Length, $3 \mathrm{~mm}$.

One specimen collected by Mr. R. J. Crew, at Bartica, British Guiana, July 3, 1901. Type in the author's collection. 

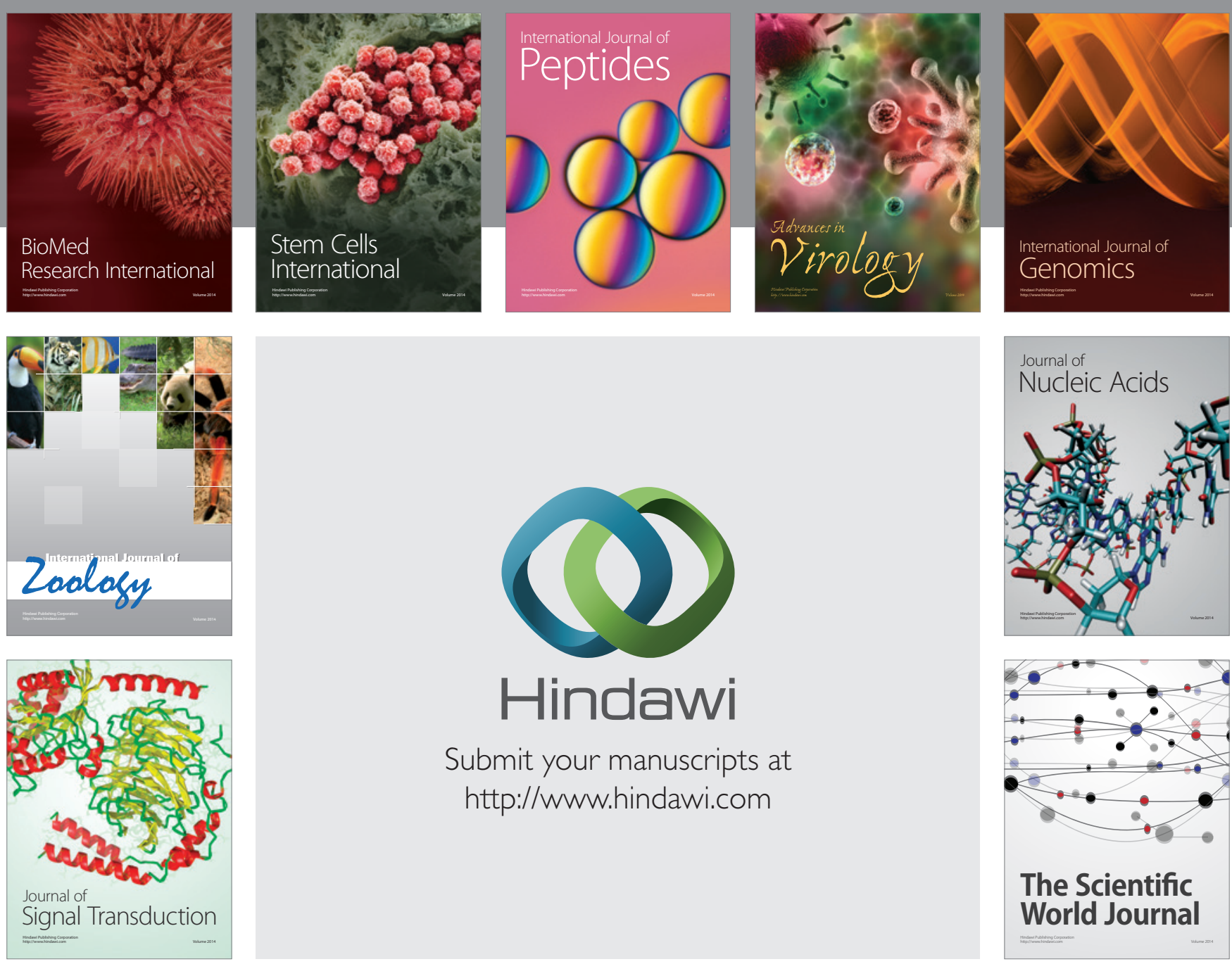

Submit your manuscripts at

http://www.hindawi.com
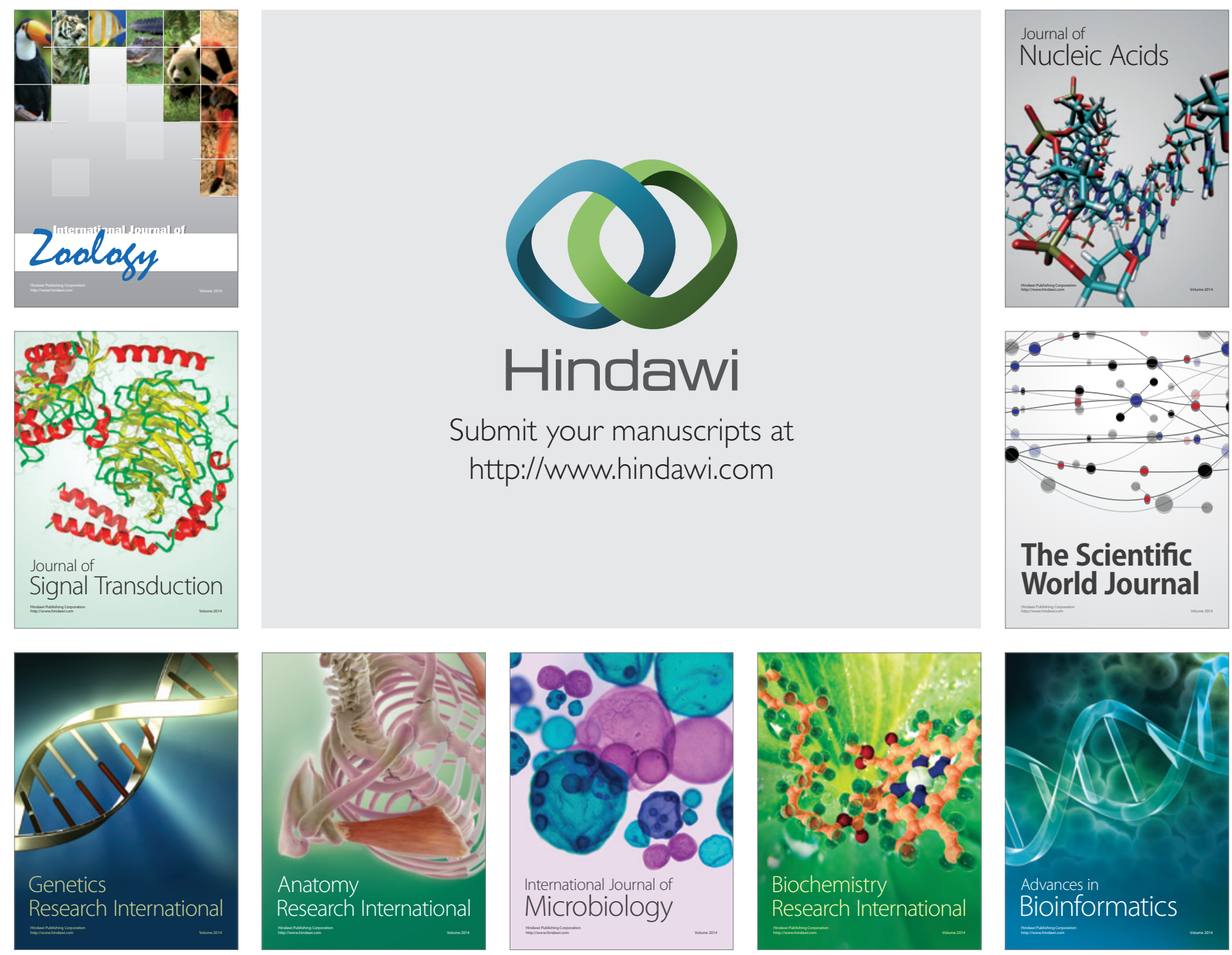

The Scientific World Journal
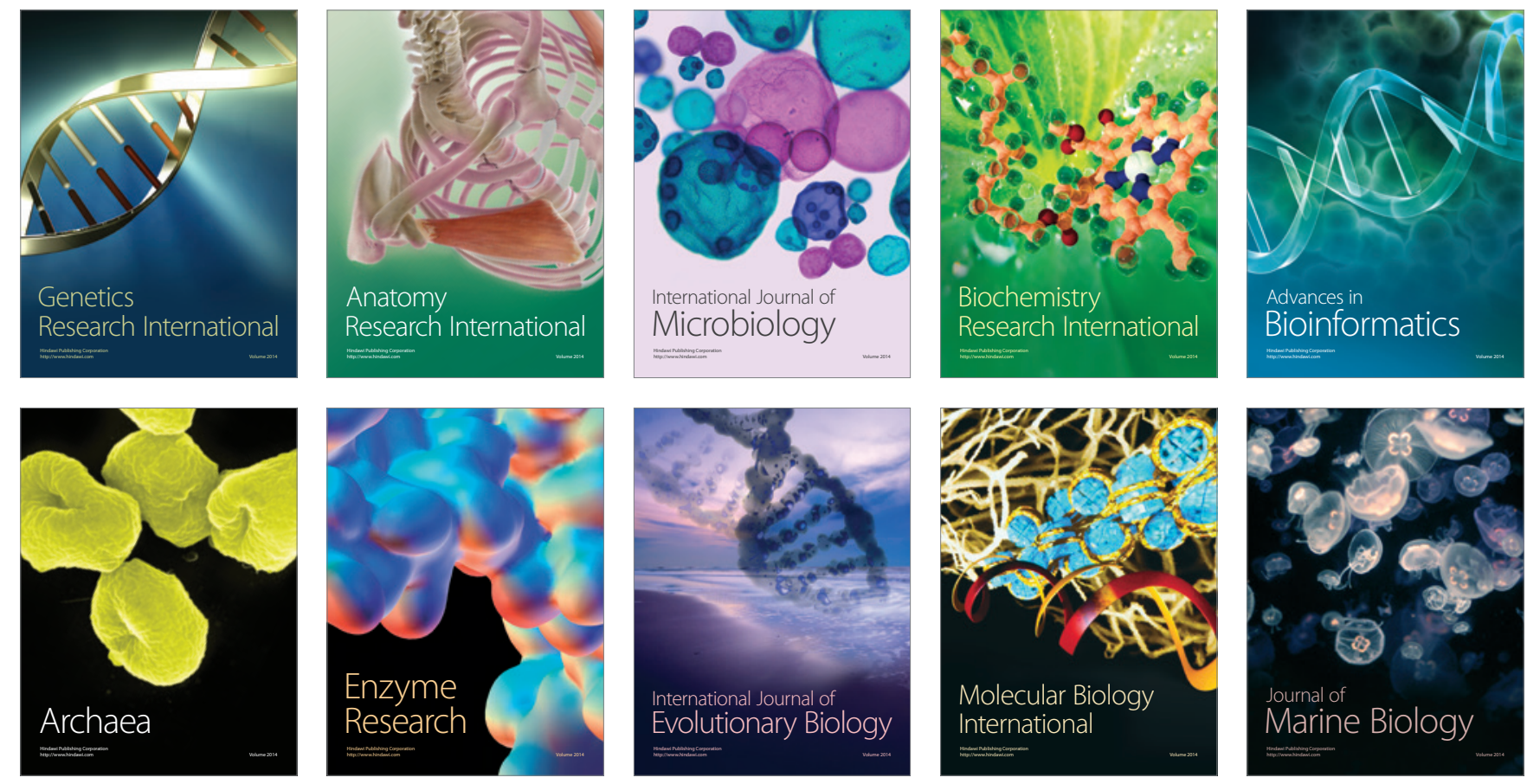